\title{
Synthesis and Characterization of Trimetallic Fe-Co-V/Zeolite and Fe-Co-Mo/Zeolite Composite Nanostructures
}

\author{
Abdolreza Karbul ${ }^{a}$, Mohammad Kazem Mohammadi * (D), Reza Jalilzadeh Yengejeh ${ }^{a}$,
}

\author{
Forouzan Farrokhian
}

\author{
${ }^{a}$ Islamic Azad University Ahvaz Branch, Department of Environmental Engineering, Ahvaz, Iran \\ ${ }^{b}$ Islamic Azad University Ahvaz Branch, Department of Chemistry, Ahvaz, Iran \\ 'Islamic Azad University Ahvaz Branch, Department of Environment, Ahvaz, Iran
}

Received: July 03, 2020; Revised: October 10, 2020; Accepted: October 23, 2021

The facile chemical synthesis method was used for preparing Trimetallic Fe-Co-V/Zeolite and $\mathrm{Fe}-\mathrm{Co}-\mathrm{Mo} / \mathrm{Zeolite}$ composite nanostructures. The structural functionalities and morphological observations were obtained using characterization techniques of field emission scanning electron microscopy (FESEM), X-ray diffraction (XRD), Fourier transfer infrared (FT-IR) spectroscopy, and energy dispersive spectroscopy (EDS). The results indicated the formation of irregular and no-shaped nanostructures for both $\mathrm{Fe}-\mathrm{Co}-\mathrm{V} / \mathrm{Z}$ eolite and $\mathrm{Fe}-\mathrm{Co}-\mathrm{Mo} / \mathrm{Zeolite}$ composite nanostructures. The optical characterization was conducted by UV-Vis diffuse reflectance spectroscopy (UV-Vis DRS). The optical studies were revealed band-gap energies equivalent to 3.0 and $3.5 \mathrm{eV}$ for $\mathrm{Fe}-\mathrm{Co}-\mathrm{V} / \mathrm{Zeolite}$ and $\mathrm{Fe}-\mathrm{Co}-$ $\mathrm{Mo} /$ Zeolite samples. The morphological features of sample were investigated with a Zeiss (EM10C -Germany) transmission electron microscope (TEM) operating at $100 \mathrm{kV}$ respectively.

Keywords: Zeolite, synthesis, characterization, nanostructures.

\section{Introduction}

With the development of nanotechnology, catalysts made of transition metals have drawn a lot of attention due to their application in various areas including catalytic hydrogenation, rechargeable batteries, and wastewater treatment ${ }^{1}$. Transition metals (Co, Fe, Ni, Mo, Mn, and Zn, etc.) exhibit significant advantages such as being inexpensive, non-toxic, and abundant in the earth ${ }^{2}$. In this regard, Bonin et al. ${ }^{3}$ reviewed recent developments of electrochemical and photochemical $\mathrm{CO}_{2}$ reduction molecular catalysis with a metal-based $\mathrm{Fe}$ and Co complex. He et al. ${ }^{4}$ increased atomic utilization and electronic regulation for promoting ORR catalysis and proposed a practicable strategy for the Pt-Fe intermetallic catalysts'synthesis. Youn et al. ${ }^{5}$ described the morphological evolution of Fe-Mo bimetallic catalysts for the vertically aligned carbon nanotubes' diameter and density features modulation. The applications of $\mathrm{N}^{\wedge} \mathrm{O}$ (ethylimino-methyl) phenol $\mathrm{Fe}$ (II) and $\mathrm{Co}$ (II) complexes in ethylene oligomerization catalysis and their structural elucidation were studied by Ngcobo et al. ${ }^{6}$. In artificial photosynthetic systems, hydrogen is generated with molecular catalysts of $\mathrm{Co}, \mathrm{Ni}, \mathrm{Fe}$, and $\mathrm{Mo}^{7}$. $\mathrm{Du}$ et al. ${ }^{2}$ carried out theoretical and experimental studies on metal-organic framederived ( $\mathrm{M}=\mathrm{Fe}, \mathrm{Ni}, \mathrm{Zn}$, and $\mathrm{Mo}$ ) which were doped into $\mathrm{Co}_{9} \mathrm{~S}_{8}$ nanoarrays as an efficient electrocatalyst for water splitting.

In the last few decades, various pollutants released into water environments have brought serious threats to human health and aquatic ecosystems. Therefore, several efforts

*e-mail: mkmohamadi@gmail.com have been dedicated to the synthesis of metallic nanoparticles as effective catalysts for the removal of such hazardous pollutants. Rahim Pouran et al. ${ }^{8}$ described a novel adsorbent and heterogeneous catalyst for wastewater treatment in a review study. They studied transition metal-substituted magnetite. $\mathrm{H}_{2} \mathrm{O}_{2}$ and formic acid were utilized as oxidants for the analyzing $\mathrm{Fe}$ (highly cost-effective and efficient metal) incorporation to $\mathrm{Co}$ or $\mathrm{Ni}$-based $\mathrm{Mo} / \mathrm{Al}_{2} \mathrm{O}_{3}$ catalysts in oxidative desulfurization (ODS) of Dibenzothiophene (DBT) ${ }^{9}$. $\mathrm{Xu}$ et al. ${ }^{10}$ studied photoredox degradation of different water pollutants by using $\mathrm{Fe}-\mathrm{N}$-S-tri-doped $\mathrm{TiO}_{2}$ nano photocatalyst prepared by a novel chemical method. Kim et al. ${ }^{11}$ used Fe and Al electrodes and demonstrated the removal mechanism of heavy metals. Allaedini et al. ${ }^{1}$ synthesized trimetallic catalyst nanoparticles (Fe-Ni-Ce) to examine the catalytic degradation of methylene blue (MB) dye. Pirsaheb et al. ${ }^{12}$ defined the methyl orange removal from aqueous media with immobilized scoriaNi/TiO 2 nanoparticles.

A combination of metallic and acidic sites in a single nanocomposite material has been attractive for catalytic application for several decades. High thermal stability, high acidity, and unique nanometric porous network of the zeolites made them the best candidates for introducing an acidic function. There are several catalytic reactions where metal-zeolite composite materials have been efficiently used ${ }^{13}$.

Zeolites with properties of porous structures have received a possibility as suitable hosts for the synthesis of nano-sized particles. Zeolite materials can be obtained via either the mining of naturally occurring phases or laboratory routes. They consist of alumina $\left(\mathrm{Al}_{2} \mathrm{O}_{3}\right)$ and silica $\left(\mathrm{SiO}_{2}\right)$ with 
alkali or alkaline-earth metals, and water trapped molecules in gaps ${ }^{14,15}$. Zeolites possess regular microspheres of one-, two- and three-dimensions creating a vast network of channels and cages with well-defined sizes and shapes ${ }^{16}$. In this regard, $\mathrm{Xu}$ et al. ${ }^{17}$ presented a review report on the encapsulation of metal nanoparticle catalysts. Farrusseng and Tue ${ }^{18}$ also exhibited perspectives and applications of zeolite-encapsulated metal nanoparticles in catalysis. Wu et al. ${ }^{19}$ explained the noble nanometals confinement in a zeolite matrix. They showed significant benefits in size and site adjustment, and nano-architecture design. A novel supercluster with a structural geometry was the result of CdS nanoparticles' direct synthesis ${ }^{20}$. Wang and Herron ${ }^{21}$ reported the preparation and optical studies of $\mathrm{CdS}$ and $\mathrm{PbS}$ semiconductor clusters encapsulated in zeolite structures. Pt-Sn sub-nanometer clusters in sinusoidal zeolite channels were described by M. Weckhuysen ${ }^{22}$ and lead to the improved and more stable propane dehydrogenation catalysts. The activity and stability of H-ZSM-5 zeolite considering the impact of Fe-Mo, Co-Mo, and Ni-Mo bimetallic additives was investigated for the isomerization of 1 -hexene ${ }^{23}$. Ito et al. ${ }^{24}$ reported the removal of sulfamethazine with $\mathrm{TiO}_{2}$-zeolite composites in good yield. Jagannatha et al. ${ }^{25}$ reported the $\mathrm{ZnO}$ Zeolite Nanocomposite synthesis for the Benzophenone and Caffeine Photocatalytic removal. It showed $85 \%$ caffeine degradation and $78 \%$ of BP-3 degradation. $0.7 \mathrm{gm} / \mathrm{L}$ was the optimum catalyst load for the degradation of pollutants, as evidenced by the studies.

In recent years, several researchers have sought the effect of trimetallic catalysts made of transition metals on catalytic capabilities. However, no studies have been found which survey the synthesis of Fe-Co-V/Zeolite and $\mathrm{Fe}-\mathrm{Co}-\mathrm{Mo} / \mathrm{Zeolite}$ composite nanostructures.

In continuation of our interest in the synthesis of new nanostructure compounds that have an application for synthesis of new metal-organic frameworks and wastewater removal ${ }^{26,27}$, We used this method for the synthesis of these new composite compounds corresponded to deposition methods mentioned in reported articles ${ }^{28,29}$.

Herein, we report the preparation of trimetallic Fe-Co- $\mathrm{V}$ and $\mathrm{Fe}-\mathrm{Co}-\mathrm{Mo}$ structures on zeolite materials as host beds by a facile chemical synthesis route and the characterization of synthesized samples using XRD, FT-IR spectroscopy, FESEM and UV-Vis DRS. We use these nanocomposites based on zeolite for the removal of selected organic dyes from wastewater in the following and planning the next works.

\section{Experimental}

\subsection{Materials}

To carry out this research, reagents, vanadium pentoxide $\left(\mathrm{V}_{2} \mathrm{O}_{5}\right)$, sodium hydroxide $(\mathrm{NaOH})$, iron (III) nitrate $(\mathrm{Fe}$ $\left.\left(\mathrm{NO}_{3}\right)_{3}\right)$ and cobalt (II) nitrate $\left(\mathrm{Co}\left(\mathrm{NO}_{3}\right)_{2}\right)$, Ammonium heptamolybdate tetrahydrate $\left(\mathrm{NH}_{4}\right)_{6} \mathrm{Mo}_{7} \mathrm{O}_{24} \cdot 4 \mathrm{H}_{2} \mathrm{O}$ purchased from Merck company and used without any purifications. Sodium hydroxide $(\mathrm{NaOH})$, nitric acid $\mathrm{HNO}_{3}$, and zeolite ( $\mathrm{NaA}$ ) were purchased from Merck Company and prepared according to the requested method in the manuscript. Distilled Water is used for these synthesis methods.

\subsection{Instruments}

XRD measurements were carried out using a Ultime IV Multipurpose X-ray diffractometer (Rigaku company, USA) $3 \mathrm{~kW}$ sealed X-ray tube, D/teX Ultra silicon strip detector, equipped with $\mathrm{Cu} \mathrm{K} a_{1}(\lambda=0.15406 \mathrm{~nm})$ radiation. Fourier transform infrared (FT-IR) patterns were obtained on a Perkin Elmer BX-II spectrophotometer (Perkin Elmer Company, USA 400-4000 $\mathrm{Cm}^{-1}$ ). A FESEM, Zeiss SIGMA VP-500 (sigma company, USA) equipped with side detectors of EDS and high-resolution elemental mapping was utilized to characterize surface morphology and elemental compositions. UV-Vis DRS was performed by a UV-Vis spectrophotometer (Avaspec2048-TEC. 200 - 1100 nm. Avantes company, Holland). The morphological features of sample were investigated with a Zeiss (EM10C -Germany) transmission electron microscope (TEM) operating at $100 \mathrm{kV}$.

\subsection{Preparation of samples}

A facile chemical synthesis method was employed to fabricate trimetallic $\mathrm{Fe}-\mathrm{Co}-\mathrm{V} / \mathrm{Z}$ eolite and $\mathrm{Fe}-\mathrm{Co}-\mathrm{Mo} / \mathrm{Z}$ eolite composite nanostructures (CNs). In a typical preparation process for the fabrication of the Fe-Co-V/Zeolite sample, $3 \mathrm{mmol}(0.54 \mathrm{gr})$ of vanadium pentoxide $\left(\mathrm{V}_{2} \mathrm{O}_{5}\right)$ was first dissolved into $1 \mathrm{~mL}$ of $1 \mathrm{M}$ sodium hydroxide $(\mathrm{NaOH})$ aqueous solution. The resultant yellowish product was then filtered to remove solid impurities and treated with adding nitric acid $\left(\mathrm{HNO}_{3}\right)(10 \mathrm{ml})$ to reach a solution containing $\mathrm{V}_{10} \mathrm{O}_{28}{ }^{6-}$. The obtained pinkish solution along with a $0.35 \mathrm{gr}$ zeolite was placed into a flask equipped with a mechanical stirrer. The resulting mixture was heated at $60^{\circ} \mathrm{C}$ for $24 \mathrm{~h}$ to be completely absorbed $\mathrm{V}_{10} \mathrm{O}_{28}{ }^{6-}$ ions on the surface of the zeolite material. After that, iron (III) nitrate $\mathrm{Fe}\left(\mathrm{NO}_{3}\right)_{3}$ and cobalt (II) nitrate $\mathrm{Co}\left(\mathrm{NO}_{3}\right)_{2}$ solutions with the same molarity were added drop by drop into the above solution under continuous stirring at $60^{\circ} \mathrm{C}$ for $5 \mathrm{~h}$. The final product was filtered, dried at room temperature, and calcined at $600^{\circ} \mathrm{C}$ for $5 \mathrm{~h}$. The dried powder was finally treated in a reactor under pressure 20 bar at $500^{\circ} \mathrm{C}$ for $5 \mathrm{~h}$.

A similar synthesis route was utilized to prepare a trimetallic Fe-Co-Mo/Zeolite sample. Briefly, 3 mmol (3.48 gr) Ammonium heptamolybdate tetrahydrate $\left(\mathrm{NH}_{4}\right)_{6} \mathrm{Mo}_{7} \mathrm{O}_{24} \cdot 4 \mathrm{H}_{2} \mathrm{O}$ was dissolved into $2 \mathrm{~mL}$ of distilled water and added into $0.4 \mathrm{gr}$ of zeolite. The obtained mixture was stirred at $60^{\circ} \mathrm{C}$ for $24 \mathrm{~h}$ to be coated heptamolybdate ions on the surface of the zeolite. The obtained product was then processed exactly according to the method previously described for the fabrication of $\mathrm{Fe}-\mathrm{Co}-\mathrm{V} / \mathrm{Z}$ eolite $\mathrm{CNs}$.

\section{Results and Discussion}

Phase compositions of synthesized samples cleared using the XRD technique. Figure 1 shows XRD patterns of $\mathrm{Fe}-\mathrm{Co}-\mathrm{V} / \mathrm{Zeolite}$ and $\mathrm{Fe}-\mathrm{Co}-\mathrm{Mo} / \mathrm{Zeolite} \mathrm{CNs}$. It can be found from Figure 1 that both samples indicate the presence of zeolite crystals by showing cubic Sodium Aluminosilicate Hydrate $\left(\mathrm{Na}_{2} \mathrm{Al}_{2} \mathrm{SiO}_{6} \cdot \mathrm{xH}_{2} \mathrm{O}\right)$ with space group Im3m (Card No. 00-018-1198). The XRD pattern of $\mathrm{Fe}-\mathrm{Co}-\mathrm{V} / \mathrm{Zeolite} \mathrm{CNs}$ also presents phases relevant to $\mathrm{Fe}_{3} \mathrm{O}_{4}(01-076-0958), \mathrm{Fe}_{2} \mathrm{O}_{3}(00-025-1402), \mathrm{V}_{2} \mathrm{O}_{5}(00-003-0206)$, and $\mathrm{CoFe}_{2} \mathrm{O}_{4}(01-079-1744)$ structures due to the existence 
of $\mathrm{Fe}, \mathrm{Co}, \mathrm{V}$, and $\mathrm{Na}$ elements, respectively. It is clear from Figure 1 that $\mathrm{Fe}-\mathrm{Co}-\mathrm{Mo} / \mathrm{Zeolite}$ sample consists of $\mathrm{Fe}_{2}\left(\mathrm{MoO}_{4}\right)$ (00-035-0183), $\mathrm{Fe}_{2} \mathrm{O}_{3}(00-025-1402), \mathrm{MoO}_{3}(01-084-1360)$, and $\mathrm{CoFe}_{2} \mathrm{O}_{4}(01-079-1744)$ phases confirming the presence of $\mathrm{Fe}, \mathrm{Co}, \mathrm{Mo}$, and $\mathrm{Na}$ elements.

The chemical bond types and vibrational properties of as-synthesized samples were investigated using FT-IR spectroscopy. Figure 2 presents the FT-IR spectra of Fe$\mathrm{Co}-\mathrm{V} /$ Zeolite and $\mathrm{Fe}-\mathrm{Co}-\mathrm{Mo} /$ Zeolite $\mathrm{CNs}$ in the wavenumber ranged from 400 to $4000 \mathrm{~cm}^{-1}$. The bands at 458 and $463 \mathrm{can}$ be assigned to the bending vibrations of the T-O ( $\mathrm{T}=\mathrm{Al}, \mathrm{Si}$ groups) in the zeolite ${ }^{30,31}$. This band also depicted the bending vibration of internal tetrahedron $\mathrm{TO} 4$ of the zeolite structure.

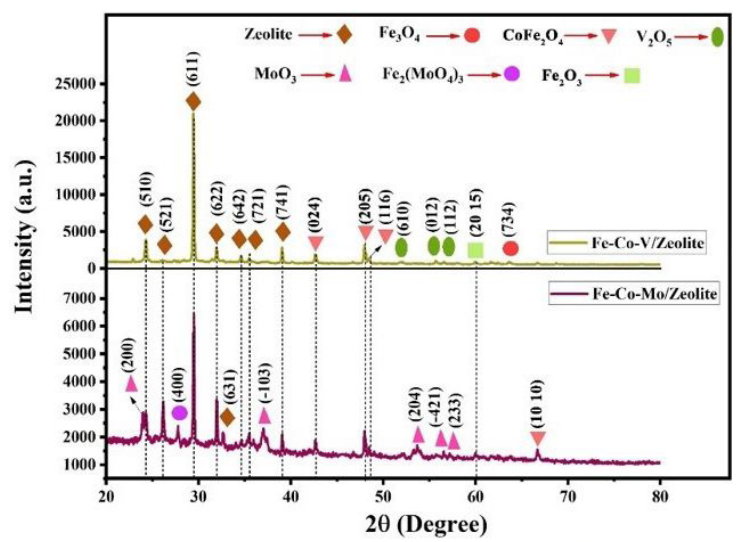

Figure 1. XRD spectra of Fe-Co-V/Zeolite and $\mathrm{Fe}-\mathrm{Co}-\mathrm{Mo} / \mathrm{Zeolite} \mathrm{CNs}$.

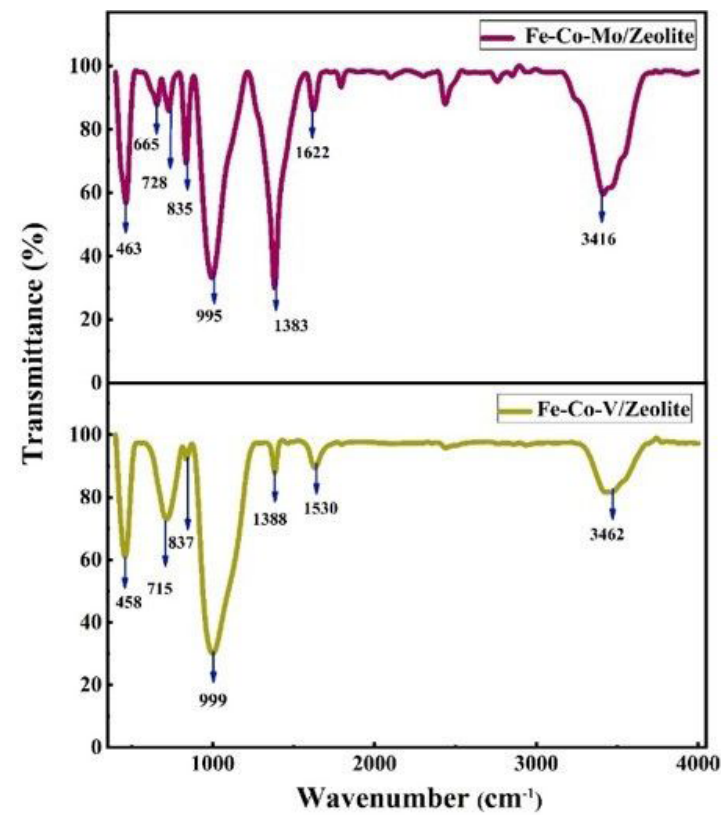

Figure 2. FT-IR spectra of Fe-Co-V/Zeolite and $\mathrm{Fe}-\mathrm{Co}-\mathrm{Mo} / \mathrm{Zeolite} \mathrm{CNs}$.
This also showed the presence of $\mathrm{Al}^{+3}$ and $\mathrm{Si}^{4+}$ in the zeolite. The bands at $665 \mathrm{~cm}^{-1}$ can refer to $\mathrm{Si}-\mathrm{O}-\mathrm{Si}$, while bands at 715 and $728 \mathrm{~cm}^{-1}$ can be due to the symmetrical stretching $(\mathrm{T}-\mathrm{O}-\mathrm{T}, \mathrm{T}=\mathrm{Si}, \mathrm{Al})^{32}$. The peaks at 835 and $837 \mathrm{~cm}^{-1}$ can be ascribed to $\mathrm{Fe}-\mathrm{OH}$ bending vibrations ${ }^{33}$. The strong bands observed around 995 and $999 \mathrm{~cm}^{-1}$ can be assigned to overlapping the symmetric vibrations of Si-O (bridging) and $\mathrm{Si}^{-} \mathrm{O}^{-}$(non-bridging) bonds ${ }^{33}$. The peaks at 1383 and $1388 \mathrm{~cm}^{-1}$ can be attributed to the $\mathrm{C}-\mathrm{N}$ bending vibrations ${ }^{34}$. For the Fe-Co-V/Zeolite, a weak peak observed could due to weaker interaction of $\mathrm{V}$ metal with the zeolite surface. The bands located at 1530 and $1622 \mathrm{~cm}^{-1}$ can be related to $\mathrm{OH}$ bending vibration of water molecules, while those appeared at 3416 and $3462 \mathrm{~cm}^{-1}$ are due to $\mathrm{OH}$ stretching vibrations of water ${ }^{34}$

Spectra at $2355 \mathrm{~cm}^{-1}$ could be due to the interaction between $\mathrm{Fe}-\mathrm{Co}-\mathrm{Mo}, \mathrm{Fe}-\mathrm{Co}-\mathrm{V}$ ions, and $\mathrm{TO}_{4}$ in the zeolite during the doping process. Because of weak dative covalent bonding in the $\mathrm{V}$ metal, this peak observed very weak in this spectrum ${ }^{35,36}$.

The as-synthesized samples morphological characteristics were were studied by FESEM. Figure 3 displays FESEM images of $\mathrm{Fe}-\mathrm{Co}-\mathrm{V} / \mathrm{Zeolite}$ and $\mathrm{Fe}-\mathrm{Co}-\mathrm{Mo} / \mathrm{Zeolite} \mathrm{CNs}$ in two different magnifications. Figure 3 a presents the overall image of Fe-Co-V/Zeolite CNs consisting of an aggregation of irregular shapes. The high-resolution image is shown in Figure $3 \mathrm{~b}$ indicates rough surfaces for $\mathrm{Fe}-\mathrm{Co}-\mathrm{V} / \mathrm{Z}$ eolite $\mathrm{CNs}$ due to the formation of spherical nanoparticles with a size ranging from 20 to $60 \mathrm{~nm}$. It can be also seen in Figure 3c that $\mathrm{Fe}-\mathrm{Co}-\mathrm{Mo} / \mathrm{Zeolite}$ sample includes no-shaped structures composed of nanoparticles with a particle size of 20 to $110 \mathrm{~nm}$ (Figure 3d).

The surface elemental distribution of as-synthesized samples was examined by FESEM-EDS mapping. Figure 4 shows FESEM images and the corresponding elemental mappings for $\mathrm{Fe}-\mathrm{Co}-\mathrm{V} / \mathrm{Zeolite}$ and $\mathrm{Fe}-\mathrm{Co}-\mathrm{Mo} / \mathrm{Zeolite} \mathrm{CNs}$. Figure $4 \mathrm{~b}$ exhibits the uniform existence of $\mathrm{Al}, \mathrm{Si}, \mathrm{Fe}, \mathrm{Co}, \mathrm{O}$, and $\mathrm{V}$ elements in the boxed surface area for Fe-Co-V/Zeolite sample (Figure 4a). It can be also seen in Figure $4 \mathrm{~d}$ that $\mathrm{Fe}-\mathrm{Co}-\mathrm{Mo} /$ Zeolite sample presents a uniform distribution of $\mathrm{Al}, \mathrm{Si}, \mathrm{Fe}, \mathrm{Co}, \mathrm{O}$, and Mo elements in the surface area selected in Figure 4c. The quantitative elemental analysis for $\mathrm{Fe}-\mathrm{Co}-\mathrm{V} /$ Zeolite and $\mathrm{Fe}-\mathrm{Co}-\mathrm{Mo} / \mathrm{Zeolite}$ samples was also carried out using recording EDX spectra as shown in Figure 5. Resulted spectra indicate the presence of $\mathrm{Al}, \mathrm{Si}$, $\mathrm{Fe}, \mathrm{Co}, \mathrm{O}$, and $\mathrm{V}$ elements and $\mathrm{Al}, \mathrm{Si}, \mathrm{Fe}, \mathrm{Co}, \mathrm{O}$, and $\mathrm{Mo}$ elements in $\mathrm{Fe}-\mathrm{Co}-\mathrm{V} / \mathrm{Z}$ eolite and $\mathrm{Fe}-\mathrm{Co}-\mathrm{Mo} / \mathrm{Zeolite} \mathrm{CNs}$, respectively. Table 1 summarizes the numerical analysis of EDX spectra for as-synthesized samples.

V-Vis DRS was performed to investigate the absorption characteristics of as-synthesized samples. Figure $6 \mathrm{a}$ plots DRS patterns of $\mathrm{Fe}-\mathrm{Co}-\mathrm{V} / \mathrm{Zeolite}$ and $\mathrm{Fe}-\mathrm{Co}-\mathrm{Mo} / \mathrm{Zeolite}$ $\mathrm{CNs}$ in the wavelength range of 200 to $800 \mathrm{~nm}$. Fe-Co-V/

Table 1. Quantitative EDS analysis of Fe-Co-V/Zeolite and Fe-Co-Mo/Zeolite CNs.

\begin{tabular}{|c|c|c|c|c|c|c|c|c|c|c|c|c|c|c|}
\hline \multirow{2}{*}{ Sample } & \multicolumn{2}{|c|}{$A l$} & \multicolumn{2}{|c|}{$\mathrm{Si}$} & \multicolumn{2}{|c|}{$\mathrm{Fe}$} & \multicolumn{2}{|c|}{ Co } & \multicolumn{2}{|c|}{$O$} & \multicolumn{2}{|c|}{ V } & \multicolumn{2}{|c|}{$M o$} \\
\hline & $W t \%$ & $\sigma$ & $W t \%$ & $\sigma$ & $W t \%$ & $\sigma$ & $W t \%$ & $\sigma$ & $W t \%$ & $\sigma$ & $W t \%$ & $\Sigma$ & $W t \%$ & $\sigma$ \\
\hline $\mathrm{Fe}$-Co-V/Zeolite & 12.3 & 0.2 & 10.1 & 0.2 & 5.2 & 0.8 & 6.4 & 0.6 & 52.7 & 0.7 & 13.2 & 0.5 & ------ & ----- \\
\hline $\mathrm{Fe}-\mathrm{Co}-\mathrm{Mo} /$ Zeolite & 14.2 & 0.2 & 15.6 & 0.2 & 2.6 & 0.6 & 3.7 & 0.4 & 32.7 & 0.4 & ----- & ----- & 31.2 & 0.6 \\
\hline
\end{tabular}



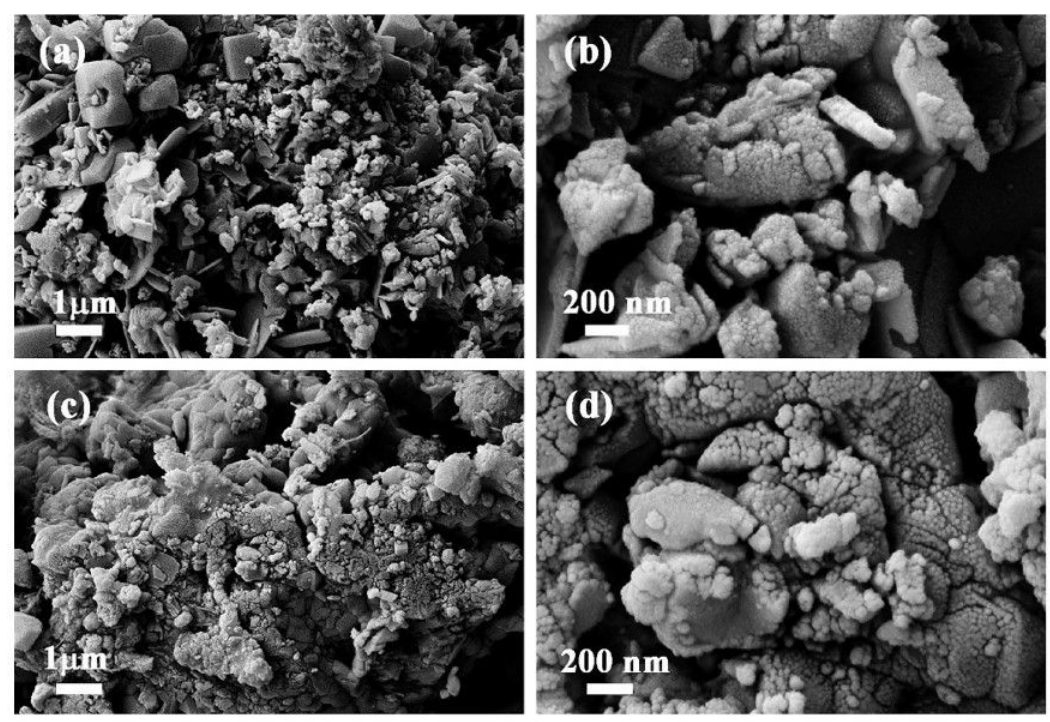

Figure 3. FESEM images of (a, b) Fe-Co-V/Zeolite and (c, d) Fe-Co-Mo/Zeolite CNs.
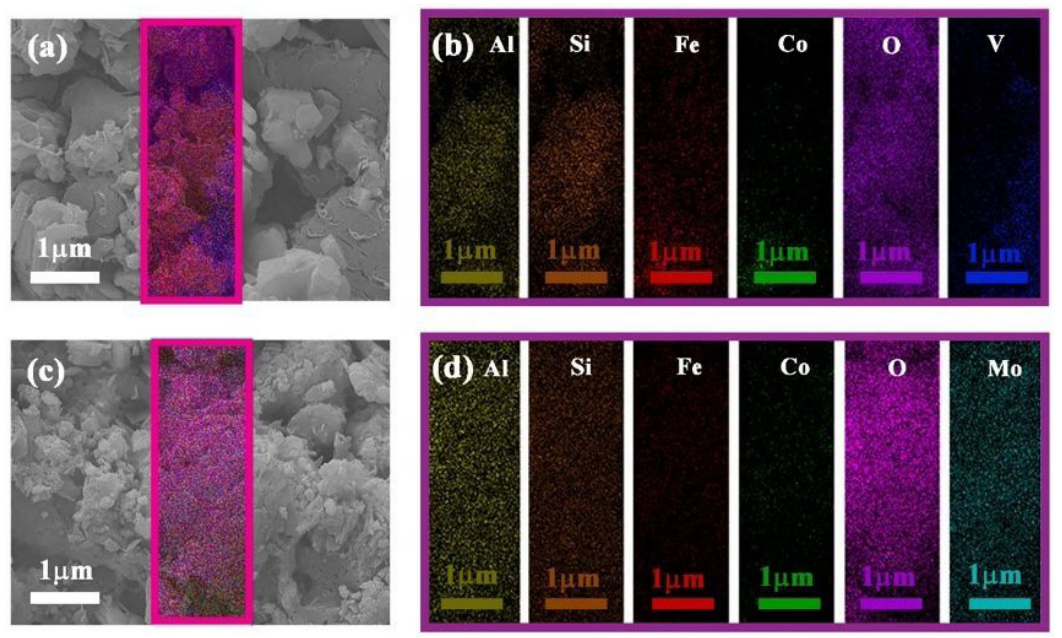

Figure 4. (a, c) FESEM map images and (b, d) the corresponding elemental mappings for (a, b) Fe-Co-V/Zeolite and (c, d) Fe-Co-Mo/ Zeolite CNs.
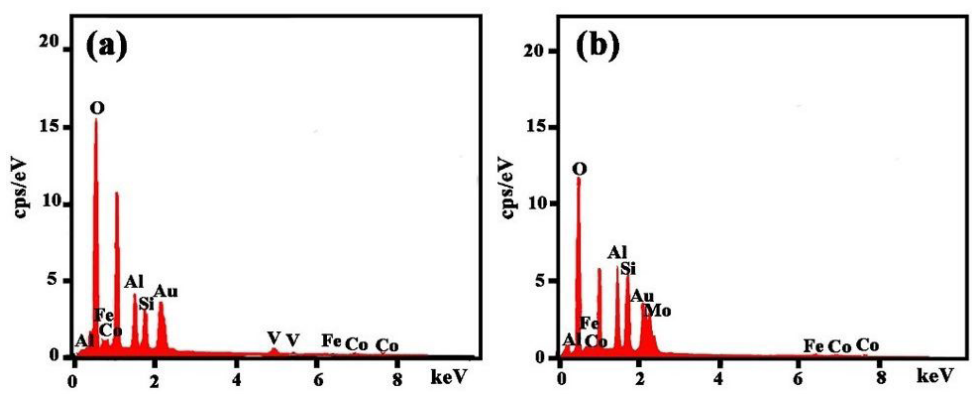

Figure 5. EDS spectra of Fe-Co-V/Zeolite and Fe-Co-Mo/Zeolite CNs.

Zeolite sample demonstrates the strong UV absorption with two recognizable peaks at 240 and $270 \mathrm{~nm}$, which can be assigned to zeolite structures. The spectral pattern of Fe-Co-V/Zeolite CNs also presents milder absorption in the visible region due to the presence of $\mathrm{Fe}, \mathrm{Co}$, and $\mathrm{V}$ elements. A relatively similar spectrum is also detected for $\mathrm{Fe}-\mathrm{Co}-\mathrm{Mo} /$ Zeolite sample with indicating a strong absorption peak at $248 \mathrm{~nm}$. A careful look at the spectral pattern of the $\mathrm{Fe}-\mathrm{Co}-\mathrm{Mo} / \mathrm{Zeolite}$ sample also reveals a milder band along with a recognizable peak at $648 \mathrm{~nm}$ related to $\mathrm{Fe}, \mathrm{Co}$, and Mo elements.

The recorded DRS patterns can be analyzed to estimate band-gap energies of $\mathrm{Fe}-\mathrm{Co}-\mathrm{V} / \mathrm{Zeolite}$ and $\mathrm{Fe}-\mathrm{Co}-\mathrm{Mo} / \mathrm{Zeolite}$ CNs using Kubelka-Munk theory as ${ }^{37-39}$ : 

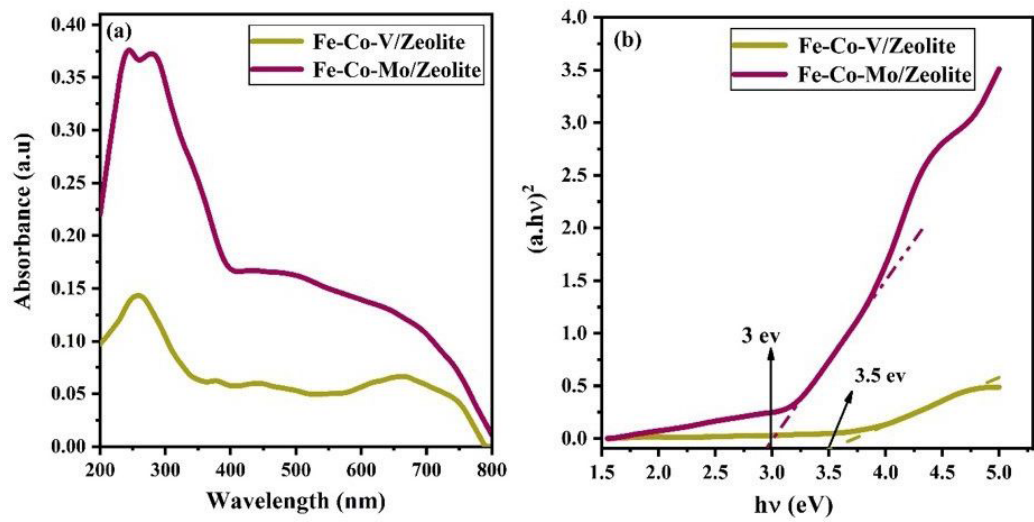

Figure 6. (a) UV-Vis DRS absorption patterns and (b) the corresponding Tauc plots for Fe-Co-V/Zeolite and Fe-Co-Mo/Zeolite CNs.
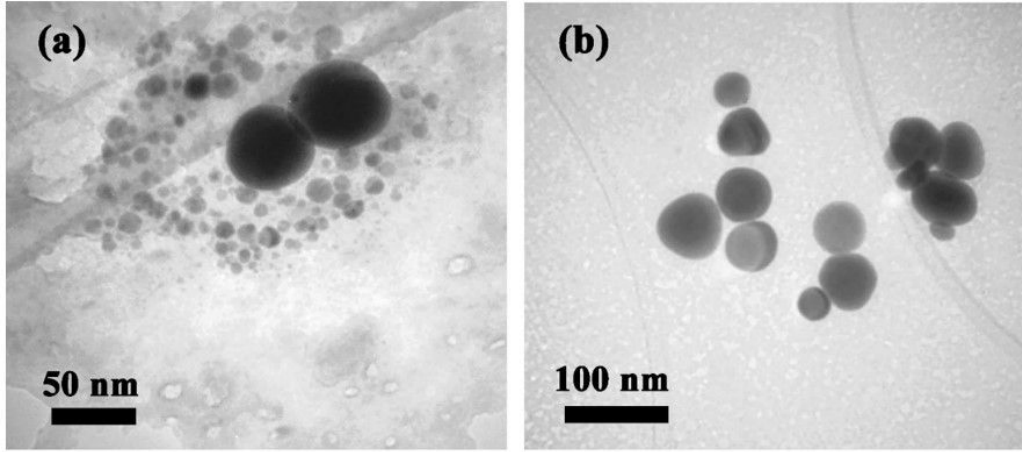

Figure 7. (a) TEM image of Fe-Co-V/Zeolite CNs and (b) TEM image of Fe-Co-Mo/Zeolite CNs.

$$
(a h \vartheta)=A\left(h \vartheta-E_{g}\right)^{1 / 2}
$$

Where $\alpha$ is the absorption coefficient, $h$ is Planck's constant, $v$ is the light frequency, and $A$ is the proportionality constant. The optical band-gap is calculated from the extrapolation of $(a h v)^{2}$ versus $h v$ to zero. Tauc plots for $\mathrm{Fe}-\mathrm{Co}-\mathrm{V} / \mathrm{Z}$ eolite and $\mathrm{Fe}-\mathrm{Co}-\mathrm{Mo} / \mathrm{Zeolite}$ samples are shown in Figure 6b. As shown in Figure 6b, band-gap energies are estimated to be about 3.0 and $3.5 \mathrm{eV}$ for $\mathrm{Fe}-\mathrm{Co}-\mathrm{V} / \mathrm{Z}$ eolite and $\mathrm{Fe}-\mathrm{Co}-\mathrm{Mo} / \mathrm{Zeolite}$ samples, respectively.

The morphological features of sample were investigated with a Zeiss (EM10C -Germany) transmission electron microscope (TEM) operating at $100 \mathrm{kV}$. These images were prepared as follows: The dilute aqueous solution of the sample was sonicated for $15 \mathrm{~min}$. Then, a portion of sample $(20 \mu \mathrm{L})$ was dropped onto holey carbon film on copper grid 300 mesh (EMS-USA) and dried thoroughly at room temperature.

For the closer look of synthesized microstructures, used of transmission electron microscope (TEM). Transmission electron microscope image of Fe-Co-V/Zeolite $9 \mathrm{Fe}-\mathrm{Co}-\mathrm{Mo} /$ Zeolite CNs, showed in the Figure 7. In the Figure 7a, TEM image of $\mathrm{Fe}-\mathrm{Co}-\mathrm{V} / \mathrm{Zeolite} \mathrm{CNs}$ to be observed with the $50 \mathrm{~nm}$ magnification. According to this figure, it can be said that the particles have an almost spherical surface morphology with the different particle sizes. Tem image of Fe-Co-Mo/Zeolite CNs nano particles (Figure 7b), to be observed with the $100 \mathrm{~nm}$ magnification. This image clearly shows that nano particles have an irregular surface morphology.

\section{Conclusions}

A facile chemical synthesis method was utilized to prepare trimetallic $\mathrm{Fe}-\mathrm{Co}-\mathrm{V} / \mathrm{Zeolite}$ and $\mathrm{Fe}-\mathrm{Co}-\mathrm{Mo} /$ Zeolite composite nanostructures. The formation and elemental compositions of composite structures were studied using a series of spectroscopic techniques including XRD, FT-IR, FESEM, and EDS. The UV-Vis was used to investigate linear optical characteristics indicating a strong absorption in the $\mathrm{UV}$ region with band-gapes of about 3.0 and $3.5 \mathrm{eV}$ for Fe-Co-V/Zeolite and $\mathrm{Fe}-\mathrm{Co}-\mathrm{Mo} /$ Zeolite composite nanostructures, respectively.

In conclusion, zeolite nanocomposites synthesized for the first time by the continuous one step that resulted in the formation of trimetallic $\mathrm{Fe}-\mathrm{Co}-\mathrm{V} / \mathrm{Z}$ eolite and $\mathrm{Fe}-\mathrm{Co}-\mathrm{Mo} / \mathrm{Zeolite}$ composite nanostructures. Resulted in nanostructured composites were in nano-sized form and stable in the synthesis process. Zeolite nanocomposites are provided by the simple method of cold impregnation. It is established that the physicochemical properties (Composition of nanoparticles, degree of amorphicity, size of crystallites and nanoparticles, and specific surface area) theses nanocomposites and the characteristics of zeolites, significantly affect the interaction of used metals nanoparticles with zeolites. It is found that the application of this method during the synthesis of nanocomposites leads to a decrease in the size of crystallites, an increase in the number of spherical formations when compared to the samples without treatment, and their aggregation into larger formations. These zeolite nanocomposites have a potential for use as a catalyst for organic synthesis and absorbent in waste treatment according to large surface area and existence of metals with the oxidant activity. 


\section{Acknowledgment}

The current study was partially supported by the Ahvaz Branch of Islamic Azad University. The authors would like to thank the Research Council for their generous support of this work.

\section{Reference}

1. Allaedini G, Tasirin SM, Aminayi P. Synthesis of Fe-Ni-Ce trimetallic catalyst nanoparticles via impregnation and coprecipitation and their application to dye degradation. Chem Pap. 2016;70(2):231-42.

2. Du X, Su H, Zhang X. Metal-organic framework-derived $\mathrm{M}(\mathrm{M}=\mathrm{Fe}, \mathrm{Ni}, \mathrm{Zn}$, and $\mathrm{Mo})$ doped Co9S8 nanoarrays as efficient electrocatalyst for water splitting: the combination of theoretical calculation and experiment. J Catal. 2020;383:10316.

3. Bonin J, Maurin A, Robert M. Molecular catalysis of the electrochemical and photochemical reduction of $\mathrm{CO}_{2}$ with $\mathrm{Fe}$ and Co metal-based complexes: recent advances. Coord Chem Rev. 2017;334:184-98.

4. He C, Ma Z, Wu Q, Cai Y, Huang Y, Liu K, et al. Promoting the ORR catalysis of Pt-Fe intermetallic catalysts by increasing atomic utilization and electronic regulation. Electrochim Acta. 2020;330:135119.

5. Youn SK, Park HG. Morphological evolution of Fe-Mo bimetallic catalysts for diameter and density modulation of vertically aligned carbon nanotubes. J Phys Chem C. 2013;117(36):18657-65.

6. Ngcobo M, Nyamato GS, Ojwach SO. Structural elucidation of $\mathrm{N}^{\wedge} \mathrm{O}$ (ethylimino-methyl)phenol $\mathrm{Fe}(\mathrm{II})$ and $\mathrm{Co}(\mathrm{II})$ complexes and their applications in ethylene oligomerization catalysis. Mol. Catal. 2019;478:110590.

7. Eckenhoff WT. Molecular catalysts of Co, Ni, Fe, and Mo for hydrogen generation in artificial photosynthetic systems. Coord Chem Rev. 2018;373:295-316.

8. Rahim Pouran S, Bayrami A, Abdul Aziz AR, Wan Daud WMA, Shafeeyan MS. Ultrasound and UV assisted Fenton treatment of recalcitrant wastewaters using transition metal-substitutedmagnetite nanoparticles. J Mol Liq. 2016;222:1076-84.

9. Muhammad Y, Shoukat A, Rahman AU, Rashid HU, Ahmad W. Oxidative desulfurization of dibenzothiophene over Fe promoted $\mathrm{Co}-\mathrm{Mo} / \mathrm{Al}_{2} \mathrm{O}_{3}$ and $\mathrm{Ni}-\mathrm{Mo} / \mathrm{Al}_{2} \mathrm{O}_{3}$ catalysts using hydrogen peroxide and formic acid as oxidants. Chin J Chem Eng. 2018;26:593-600.

10. Xu X, Zhou X, Zhang L, Xu L, Ma L, Luo J, et al. Photoredox degradation of different water pollutants $(\mathrm{MO}, \mathrm{RhB}, \mathrm{MB}$, and $\mathrm{Cr}(\mathrm{VI})$ ) using $\mathrm{Fe}-\mathrm{N}-\mathrm{S}$-tri-doped $\mathrm{TiO} 2$ nano photocatalyst prepared by novel chemical method. Mater Res Bull. 2015;70:106-13.

11. Kim T, Kim T-K, Zoh K-D. Removal mechanism of heavy metal $(\mathrm{Cu}, \mathrm{Ni}, \mathrm{Zn}$, and $\mathrm{Cr})$ in the presence of cyanide during electrocoagulation using $\mathrm{Fe}$ and $\mathrm{Al}$ electrodes. J Water Process Eng. 2020;33:101109.

12. Pirsaheb M, Hossaini H, Nasseri S, Azizi N, Shahmoradi B, Khosravi T. Optimization of photocatalytic degradation of methyl orange using immobilized scoriaNi/ $\mathrm{TiO}_{2}$ nanoparticles. J Nanostructure Chem. 2020;10:143-159.

13. Nyankson E, Adjasoo J, Kwame Efavi J, Yaya A, Manu G, Kingsford A, et al. Synthesis and kinetic adsorption characteristics of Zeolite/ $\mathrm{CeO}_{2}$ nanocomposite. Scient Afr. 2020;7:e00257.

14. Yoldi M, Fuentes-Ordoñez EG, Korili SA, Gil A. Zeolite synthesis from aluminum saline slag waste. Powder Technol. 2020;366:175-84.

15. Johnson CD, Worrall F. Novel granular materials with microcrystalline active surfaces: waste water treatment applications of zeolite/ vermiculite composites. Water Res. 2007;41:2229-35.

16. Jahangirian $H$, Rafiee-Moghaddam R, Jahangirian N, Nikpey B, Jahangirian S, Bassous N, et al. Green synthesis of zeolite/
$\mathrm{Fe}_{2} \mathrm{O}_{3}$ nanocomposites: toxicity \& cell proliferation assays and application as a smart iron nano fertilizer. Int J Nanomedicine. 2020;15:1005-20.

17. Xu D, Lv H, Liu B. Encapsulation of metal nanoparticle catalysts within mesoporous zeolites and their enhanced catalytic performances: a review. Front Chem. 2018;6:550.

18. Farrusseng D, Tuel A. Perspectives on zeolite-encapsulated metal nanoparticles and their applications in catalysis. New J Chem. 2016;40(5):3933-49.

19. Wu SM, Yang XY, Janiak C. Confinement effects in zeoliteconfined noble metals. Angew Chem. 2019;131(36):12468-82.

20. Herron N, Wang Y, Eddy MM, Stucky GD, Cox DE, Moller K, et al. Structure and optical properties of cadmium sulfide superclusters in zeolite hosts. J Am Chem Soc. 1989;111(2):530-40.

21. Wang Y, Herron N. Optical properties of cadmium sulfide and lead (II) sulfide clusters encapsulated in zeolites. J Phys Chem. 1987;91(2):257-60.

22. Weckhuysen BM. Stable platinum in a zeolite channel. Nat Mater. 2019;18(8):778-9.

23. Kostyniuk A, Key D, Mdleleni M. 1-hexene isomerization over bimetallic M-Mo-ZSM-5 (M: Fe, Co, Ni) zeolite catalysts: Effects of transition metals addition on the catalytic performance. J. Energy Inst. 2020;93(2):552-64.

24. Ito M, Fukahori S, Fujiwara T. Adsorptive removal and photocatalytic decomposition of sulfamethazine in secondary e_uent using $\mathrm{TiO}_{2}$-zeolite composites. Environ Sci Pollut Res Int. 2014;21(2):834-42.

25. Jagannatha RB, Rani R, Padaki M. ZnO Zeolite nanocomposite for photocatalytic elimination of benzophenone and caffeine. Chem Sel. 2019;4(6):1989-93.

26. Mohammadi MK, Gutiérrez A, Hayati P, Mohammadi K, Rezaei R. Diverse structural assemblies and influence in the morphology of different parameters in a series of $0 \mathrm{D}$ and $1 \mathrm{D}$ mercury(II) metal-organic coordination complexes by the sonochemical process. Polyhedron. 2019;160:20-34.

27. Derakhshan-Nejad A, Rangkooy HA, Cheraghi M, Yengejeh RJ. Removal of ethylbenzene vapor pollutant from the air using $\mathrm{TiO}_{2}$ nanoparticles immobilized on the ZSM-5 zeolite under UV radiation in lab scale. J Environ Health Sci Eng. 2020;18(1):201-9.

28. Kharaji AG, Shariati A, Takassi MA. A novel $\gamma$-alumina supported Fe-Mo bimetallic catalyst for Reverse Water Gas Shift (RWGS). React Chin J Chem Eng. 2013;21(9):1007-14.

29. Takassi MA, Helalizadeh A, Jaberi Rad M. Hydrogenation of carbon monoxide and carbon dioxide over nano $\gamma$-alumina supported cobalt (III)/molybdenum catalyst. Nova J Eng Appl Sci. 2016;5:1-11.

30. Kwakye-Awuah B, Von-Kiti E, Nkrumah I, Erdoo Ikyreve R, Radecka I, Williams C. Parametric, equilibrium, and kinetic study of the removal of salt ions from Ghanaian seawater by adsorption onto zeolite X. Desalin Water Treat. 2016;57(45):21654-63.

31. Zainal Abidin A, Abu Bakar NHH, Ng EP, Tan W. Rapid degradation of methyl orange by ag doped zeolite $\mathrm{X}$ in the presence of borohydride. J Taibah Univ Sci. 2017;11(6):1070-9.

32. Wang H-L, Cui J-Y, Jiang W-F. Synthesis, characterization, and flocculation activity of novel $\mathrm{Fe}(\mathrm{OH}) 3$-polyacrylamide hybrid polymer. Mater Chem Phys. 2011;130(3):993-9.

33. Kwakye-Awuah B, Wemegah DD, Nkrumah I, Williams C, Radecka I. Antimicrobial activity of silver-zeolite LTA on heavily-contaminated underground Ghanaian waters. Int J Sci Res. 2013;2:26-31.

34. Boroglu MS, Gurkaynak MA. Fabrication and characterization of silica modified polyimide-zeolite mixed matrix membranes for gas separation properties. Polym Bull. 2011;66(4):463-78.

35. Guo X, Navrotsky A. Hydration dynamics in zeolite A: an X-ray diffraction and infrared spectroscopic study. Microporous Mesoporous Mater. 2018;268:197-201. 
36. Asiedu A, Kumar S. Kinetics and optimization of catalytic transfer hydrogenation of WCO using 2-propanol as H-donor over NiOx-MoOx-CoOx/Zeolite. Ind Eng Chem Res. 2019;58(35):15787-802.

37. Franco A Jr, Pessoni HV. Optical band-gap and dielectric behavior in Ho-doped ZnO nanoparticles. Mater Lett. 2016;180:305-8.
38. Kumar V, Singh RG, Purohit LP, Singh F. Effect of swift heavy ion on structural and optical properties of undoped and doped nanocrystalline zinc oxide films. Adv. Mat. Lett. 2013;4(6):423-7.

39. Liao G, He W, He Y. Investigation of microstructure and photocatalytic performance of a modified Zeolite supported nanocrystal $\mathrm{TiO}_{2}$ composite. Catalysts. 2019;9(6):502-15. 